\begin{tabular}{|c|c|}
\hline Title & Mechanism of the toxicity induced by natural humic acid on human vascular endothelial cells \\
\hline Author(s) & $\begin{array}{l}\text { Kihara, Y usuke; Y ustiawati; T anaka, Masato; Gumiri, Sulmin; A rdianor; Hosokawa, Toshiyuki; Tanaka, Shunitz; Saito, } \\
\text { T akeshi; Kurasaki, Masaaki }\end{array}$ \\
\hline Citation & $\begin{array}{l}\text { Environmental Toxicology, 29(8), 916-925 } \\
\text { https://doi.org/10.1002/tox.21819 }\end{array}$ \\
\hline Issue Date & $2014-08$ \\
\hline Doc URL & http://hdl.handle.net/2115/53585 \\
\hline Tyре & article (author version) \\
\hline Note & Early V iew (Online V ersion of Record published before inclusion in an issue) \\
\hline Additional Information & There are other files related to this item in HUSCAP. Check the above URL. \\
\hline File Information & KiharaET.pdf (本文) \\
\hline
\end{tabular}

Instructions for use 


\title{
Mechanism of the toxicity induced by natural humic acid on human vascular
} endothelial cells

\author{
Yusuke Kihara $^{1}$, Yustiawati ${ }^{1}$, Masato Tanaka ${ }^{2}$, Sulmin Gumiri ${ }^{3}$, Ardianor ${ }^{3}$, Toshiyuki \\ Hosokawa $^{4}$, Shunitz Tanaka ${ }^{1,5}$, Takeshi Saito ${ }^{2,6}$, Masaaki Kurasaki ${ }^{1,5,}$ \\ ${ }^{1}$ :Environmental Adaptation Science, Division of Environmental Science Development, \\ Graduate School of Environmental Science, Hokkaido University, Sapporo, JAPAN \\ 2: Higher Education Research and Development Division Institute for the Advancement \\ of Higher Education Hokkaido University, Sapporo, JAPAN \\ ${ }^{3}$ : Laboratory of Environmental Limnology, Faculty of Agriculture, University of \\ Palangka Raya, Palangka Raya, Central Kalimantan, Indonesia \\ ${ }^{4}$ : Division of Higher Education Research and Development, Institute for the \\ Advancement of Higher Education, Hokkaido University, Sapporo JAPAN \\ ${ }^{5}$ : Group of Environmental Adaptation Science, Faculty of Environmental Earth Science, \\ Hokkaido University, Sapporo, JAPAN \\ ${ }^{6:}$ Laboratory of Environmental Health Sciences, Faculty of Health Sciences, Hokkaido \\ University, Sapporo, JAPAN
}

\section{Address correspondence to:}

Dr. Masaaki KURASAKI; Group of Environmental Adaptation Science, Faculty of Environmental Earth Science, Hokkaido University, Sapporo 060-0810, Japan; Phone: +81-11-706-2243, Fax: +81-11-706-4864; E-mail:kura@ees.hokudai.ac.jp

Running title: Mechanism of the toxicity of humic acid 
ABSTRACT Humic acid, a group of high-molecular weight organic compounds characterized by an ability to bind heavy metals, is normally found in natural water. Although the impairment of vascular endothelial cells in the presence of humic substances has been reported to be involved in some diseases, the mechanisms responsible for this involvement remain unclear. In this study, we examined the cytotoxicity of humic acid obtained from peatland in Central Kalimantan, Indonesia, to human vascular endothelial cells, as well as the mechanisms behind these effects. It was found that $50 \mathrm{mg} / \mathrm{L}$ humic acid showed cytotoxicity, which we considered to be mediated by apoptosis through the mitochondrial pathway due to an increase in the expression of caspases 6 and 9 in response to humic acid administration. In addition, this cytotoxicity was enhanced when cells in this experimental system were exposed to oxidative stress, while it was decreased by the addition of vitamin C. Thus, we conclude that the apoptosis induced by humic acid depends upon oxidative stress. Furthermore, an iron chelator, DFO, showed a tendency to decrease humic acid-induced cytotoxicity, suggesting that iron may potentially mediate humic acid-induced oxidative stress. In conclusion, long-term consumption of humic acid-rich water obtained from our study area may cause damage to endothelial cells and subsequent chronic health problems.

Key Words: humic acid; tropical peatland; apoptosis; endothelial cell; oxidative stress 


\section{INTRODUCTION}

In Southeast Asia, peatlands ocuppy more than 26 million hectares, accounting for $69 \%$ of all tropical peatlands (Page et al., 2004). This includes the approximately 6 million hectares of peatland in Kalimantan, Indonesia (Radjagukguk, 1992). Natural lowland tropical peatlands are dominated by peat swamp forests and are important reservoirs of carbon. As a major component of dissolve organic carbon (DOC) is humic acid (HA), which has been shown to damage human endothelial cells (Hur et al., 2011; Hseu et al., 2002), the effects of the drinking water obtained from the Sebangau River on human health was investigated in this study.

HA forms a dark-colored mixture, comprising products of microbial degradation of organic matter. It is widely found in soil, coal, and well water, and is especially abundant in peat soil (Cavani et al., 2009; Avena and Wilkinson, 2002). HA is a major component of DOC, comprising up to $70 \%-90 \%$ of brown-colored river water (Mills et al., 1996). It contains aromatic rings and phenolic hydroxyl and carboxyl groups, which act as binding sites for metal ions (Riggle andWandruszka, 2004). Therefore, HA easily formed complexes with iron, zinc, lead, and cadmium (Kalis et al., 2006).

It had been reported that exposure to HA-containing water damages tissues and cells (Cheng et al., 2003; Hseu et al., 2008; Lu et al., 1994; Yang et al., 1996). For instance, HA has been implicated as one of the contributing factors for the development of Blackfoot disease, which is an endemic peripheral vascular disease found on the southwest coast of Taiwan (Hseu et al., 2008; Yang et al., 2002). The clinical symptoms of this disease include numbness or coldness of one or more of the extremities, resulting in black discoloration, ulceration, or gangrenous changes (Tseng et al., 2007). A causal association between consumption of well water and occurrence of blackfoot disease has 
been revealed through an epidemiological study (Tseng, 2008; Yu et al., 1984). Furthermore, it was reported in the 1980s that the artesian well water in the area of Taiwan contained a high level of fluorescent compounds that induced blackening of the tail and feet of experimental mice (Cheng et al., 1999; Huang et al., 1995). The fluorescent compounds purified from this well water were identified as HA by infrared spectrophotometry and atomic absorption spectrometry; however, further studies have found that arsenic ions may also be related to Blackfoot disease (Liao et al., 2011; Selim Reza et al., 2011).

Pathological studies have revealed two types of vascular disease among patients with Blackfoot disease: arteriosclerosis and thromboangitis (Tseng, 2005). The impairment of vascular endothelial cells at an early stage has been shown to be an important aspect of both these vascular diseases (Yu et al., 1984). While HA has previously been shown to mediate damage to human vascular endothelial cells (Lu et al., 1994; Yang et al., 1996), the mechanisms of these effects are still unknown. However, some studies have revealed that HA-mediated damage on chondrocytes and human erythrocytes occurs in response to the generation of reactive oxygen species (ROS) (Hseu et al., 2002). The oxidative damage on endothelial cells plays an important role in the pathogenesis of arteriosclerosis and thrombosis (Cheng et al., 2003). Therefore, we assessed the risk of oxidative stress caused by HA in the tropical peatlands in Indonesia. The mechanism by which HA elicits these effects in human endothelial cells was investigated in this study.

\section{MATERIALS AND METHODS}

\section{Materials}


HUVECs, a cell line of human umbilical vein endothelial cells, were purchased from Cambrex Bio Science Walkersvile (Walkersvile, MD, USA). Endothelial Cell Growth Medium-2 (EGM-2) was bought from Lonza (Basel, Switzerland). HA, DAX-8, desferrioxamine (DFO), 5,5'-dithiobis (2-nitrobenzoic acid) (DTNB), ribonuclease A (RNase), streptavidin-conjugated peroxidase, peroxidase-conjugated avidin, and ethidium bromide were obtained from Sigma-Aldrich (St. Louis, MO, USA). An SV total RNA isolation system, non-radioactive cytotoxicity assay kit, caspase assay kit, RT-PCR kit, and DNA marker were purchased from Promega (Madison, WI, USA). Ascorbic acid, Triton X-100, and trypan blue solution (0.5\%) were purchased from Nacalai Tesque (Kyoto, Japan). The DNA 7500 assay kit and RNA 6000 nano assay kit were from Agilent Technologies (Waldbronn, Germany). Other chemicals were of analytical reagent grade.

\section{Sampling sites of water and peat soil}

Sampling was conducted at Sebangau River catchment in the suburbs of Palangka Raya City in Central Kalimantan, Indonesia. Water samples were collected 3 times from two sites, one in the artificial canal and one in the Sebangau River, in June 2009, December 2010, and August 2010. Peat soil samples were collected 2 times from 3 sites in December 2010 and August 2010. Sampling sites are shown in Figure 1.

\section{DOC measurements}

DOC was measured with a TOC-analyzer TOC-5000A (Shimadzu, Kyoto, Japan), according to the instruction manual. Five milliliters of $0.1 \mathrm{M} \mathrm{HCl}$ was added to each 25 - 
$\mathrm{mL}$ sample of water before determination of DOC content.

\section{Preparation of purified HA}

Natural HA from Indonesia was purified from the peat soil obtained in the natural forest near the Sebangau River by using DAX-8 absorption chromatography, as described by Swift (1996). Commercial HA was further purified following the methods described by Lu et al. (1988). In brief, commercial HA was acidified to $\mathrm{pH} 1$ with $0.1 \mathrm{M} \mathrm{HCl}$. Following centrifugation, the supernatant was removed, and the precipitated HA was dissolved in $0.1 \mathrm{M} \mathrm{NaOH}$. This alkaline-acid treatment was repeated twice.

\section{Elemental analysis of HA}

The elemental contents of HA (carbon, hydrogen and nitrogen) were measured with a Micro Corder JM10 CHN analyzer (J-Science Lab, Kyoto, Japan), while oxygen content was calculated by normalizing the sum of the elements present in the samples $(\mathrm{C}, \mathrm{H}, \mathrm{N}$, and $\mathrm{O})$ to $100 \mathrm{wt} \%$. The ash content was determined by weighing residual materials after elemental analysis.

\section{Functional group analyses in HA}

Organic functional group analyses (total acidity, carboxyl, and carbonyl groups) were performed using the methods described by Tsutsuki and Kawatsuka (1978). Phenolic hydroxyl groups were calculated on the basis of the difference between total acidity and carboxyl group. 


\section{Metals}

The $\mathrm{Al}, \mathrm{Fe}, \mathrm{Cu}, \mathrm{Mn}, \mathrm{Zn}$, and $\mathrm{Pb}$ contents of the HA samples were measured by inductively coupled plasma mass spectrometry using an ICP-MS Seiko SPQ-6500 mass spectrometer (Tokyo, Japan), according to the instruction manual. To digest the weighed HA samples with acid, they were heated in an oven (Muffle oven; Isuzu Seisakusho, Tokyo, Japan) at $95^{\circ} \mathrm{C}$ for $3 \mathrm{hr}$ by using Teflon reactors with concentrated $\mathrm{HNO}$. The final volumes of the digested samples were made up to $10 \mathrm{~mL}$ with $1 \mathrm{M} \mathrm{HNO}$. The content of each metal is represented as nanograms of metal per milligram of HA.

\section{Cell culture and exposure to HA}

HUVECs were grown in EGM-2 medium with 2\% FBS in 5\% CO2 atmosphere. Upon reaching $90 \%$ confluence, cells were subcultured using $0.05 \%$ trypsin-EDTA, and exposed to various concentrations of HA (0-100 mg/L). Two types of HAs, HA from Indonesia and commercial HA, were assessed to compare the toxicities of different chemical compositions. Cells cultured in medium containing various concentrations of HA were also exposed to oxidant $\left(\mathrm{H}_{2} \mathrm{O}_{2} ; 10 \mu \mathrm{M}\right)$, antioxidant (vitamin $\mathrm{C} ; 10 \mu \mathrm{M}$ ), and iron chelator DFO $(20 \mu \mathrm{M})$ to determine whether cells were experiencing oxidative stress. $\mathrm{H}_{2} \mathrm{O}_{2}$ and DFO were simultaneously added with $\mathrm{HA}$, while the cells were treated with vitamin C 30 min prior to adding HA to the medium.

\section{Determination of cell viability}


Cell viability was measured by trypan blue exclusion assay. Briefly, HUVECs were incubated in medium containing $2 \%$ FBS and $0-100 \mathrm{mg} / \mathrm{L}$ of HA for $72 \mathrm{hr}$ before being stained in $0.25 \%$ trypan blue in phosphate-buffered saline. The numbers of total cells and trypan blue staining cells were counted manually using a hemocytometer. Cell viabilities are expressed as the percentage of cells positive for staining against the total number of cells in each experiment. Each experiment was repeated at least 3 times.

\section{Lactate dehydrogenase (LDH) activity assay}

Cytotoxicity was assessed by measuring the amounts of LDH in the treatment medium by using a non-radioactive cytotoxicity assay kit (Promega, WI, USA). For this assay, HUVECs were cultured in medium containing $0-100 \mathrm{mg} / \mathrm{L}$ of $\mathrm{HA}$ and $10 \mu \mathrm{M}$ of $\mathrm{H}_{2} \mathrm{O}_{2}$, vitamin $\mathrm{C}$, or DFO. After culture, $50 \mu \mathrm{L}$ of the medium was transferred to multi-titer plates, and the substrate mixture containing tetrazolium salts was added to the wells. After $0.5-\mathrm{hr}$ incubation at $37^{\circ} \mathrm{C}, 50 \mu \mathrm{L}$ of stop solution was added, and the amount of formazan dye formed was determined by measuring absorbance at $495 \mathrm{~nm}$ by using a Micro Plate Reader model 450 (BIO-RAD). Relative LDH activity was expressed as the relative change in the ratio of control groups, with the resulting values representing the cytotoxicity of HA.

\section{RT-PCR analyses for caspases}

The expression levels of caspase 6, 8 , and 9 were determined by RT-PCR. Total RNA was isolated from treated HUVECs by using an SV total RNA isolation system kit 
(Promega, WI, USA), according to the instruction manual. The resultant total RNA was reverse-transcribed to cDNA by using an Access RT-PCR introductory system (Promega, WI, USA). The transcriptase reaction was carried out at $48^{\circ} \mathrm{C}$ for $45 \mathrm{~min}$ followed by $94^{\circ} \mathrm{C}$ for $2 \mathrm{~min}$, and 40 cycles of $94^{\circ} \mathrm{C}$ for $30 \mathrm{~s}, 60^{\circ} \mathrm{C}$ for $1 \mathrm{~min}, 68^{\circ} \mathrm{C}$ for $2 \mathrm{~min}$. This was followed by a final extension time of $7 \mathrm{~min}$ at $72^{\circ} \mathrm{C}$. The primers used in this study are presented in Table I. PCR products were electrophoresed on an Agilent Technologie DNA 7500 chip (Biosizing, USA). The expression levels of the caspases and $\beta$-actin were determined using a Digital Imaging and Analysis System Agilent Technologies 2100 Bioanalyzer (Biosizing, USA), and are expressed as amounts relative to those in the control cells.

\section{Measurement of intracellular free-SH levels}

The HUVECs were harvested after being exposed to HA for 24 and $48 \mathrm{hr}$, washed with PBS, and added to $80 \mu \mathrm{L}$ of $10 \mathrm{mM} \mathrm{HCl}$. Two freeze-thaw cycles were then performed to rupture the cell membranes, and the resultant solution was centrifuged at $8000 \mathrm{~g}$ for 10 min. Intracellular free-SH levels were determined using $200 \mu \mathrm{M}$ DTNB. After 10min incubation, the absorbance at $412 \mathrm{~nm}$ was measured with a DU-65 spectrophotometer (Beckman, CA, USA). The concentrations of free-SH in the HUVECs were determined using a molecular co-efficiency factor of 13,500 per cell number $\left(1 \times 10^{5}\right)$.

\section{Statistical analysis}

All experiments were performed a minimum of three times, and data are presented as 
mean \pm S.E.M. Data were analyzed using t-tests, and differences were considered statistically significant at values of $\mathrm{p}<0.05$ and $\mathrm{p}<0.1$.

\section{RESULTS}

\section{DOC levels in the Sebangau River and artificial canal}

The DOC levels in the Sebangau River were found to be $41.3-61.0 \mathrm{mg} / \mathrm{L}$ throughout the year. However, DOC levels measured in an artificial canal of the river were lower, ranging between $20.5-53.5 \mathrm{mg} / \mathrm{L}$. This was particularly evident in December 2009 and August 2010.

HA is a major component of DOC in natural water from peatland areas, and the ratio of HA in DOC can reach up to 70\%-90\% (Mills et al., 1996). From the results of DOC determination in this area, HA concentrations were expected to be $40-50 \mathrm{mg} / \mathrm{L}$ and 20 $40 \mathrm{mg} / \mathrm{L}$ in the Sebangau River and artificial canal, respectively. Since most residents along the Sebangau River use river water as drinking water, a concentration of $50 \mathrm{mg} / \mathrm{L}$ HA was used for cell experiments in this study.

\section{Chemical analysis of $\mathrm{HA}$}

To compare the chemical compositions of the HA collected in this study and commercial HA, elemental analyses and functional group analyses were carried out as shown in Table II. The carbon content of the HAs ranged from 52\% to 61\%, which is in good agreement with values reported by Yonebayashi and Hattori (1988). As a whole, HA samples obtained from Indonesia had lower carbon content compared with commercial HA. Total acidity, as determined by carboxyl groups plus phenolic hydroxyl groups, ranged between 7.2 and $7.8 \mathrm{mmol} / \mathrm{g}$ in the HA obtained from Indonesia, while 
commercial HA was found to have a total acidity of $6.1 \mathrm{mmol} / \mathrm{g}$. Carboxyl and carbonyl groups, which have been reported to have positive correlation with humification (Yonebayashi and Hattori, 1988), were found to be present in higher numbers in commercial HA than in the HA collected from Indonesia (Table II).

\section{Determination of HA metal content}

The concentrations of $\mathrm{Al}, \mathrm{Fe}, \mathrm{Cu}, \mathrm{Mn}, \mathrm{Zn}$, and $\mathrm{Pb}$ in the $\mathrm{HA}$ from Indonesia are shown in Table III. The concentrations of $\mathrm{Al}$ and $\mathrm{Fe}$ in $\mathrm{HA}$ were 67.6 and $81.0 \mathrm{ng} / \mathrm{mg}$, respectively, while the concentration of $\mathrm{Cu}$ was $13.6 \mathrm{ng} / \mathrm{mg}$. In addition, the concentration of As was $0.75 \mathrm{ng} / \mathrm{mg}$. Since the HA samples collected in this study went through an extraction process, which could decrease ash content, HA in natural water is considered to contain higher concentrations of metal than purified HA. After DFO treatment, the concentration of Fe bound to the HA from Indonesia was decreased by around half, with a final level of $36.7 \mathrm{ng} / \mathrm{mg}$.

\section{Effects of HA on cell viability}

To determine whether HAs affect cytotoxicity, the cell viability of HUVECs treated with HAs was studied using the trypan blue exclusion method. HUVECs were cultured with HA from Indonesia or commercial HA for $72 \mathrm{hr}$ at concentrations of $0-100 \mathrm{mg} / \mathrm{L}$. The viability of HA-treated cells was shown to decrease with an increase in HA concentration in a concentration-dependant manner [Fig. 2(a)]. The viability of HUVECs exposed to $>10 \mathrm{mg} / \mathrm{L}$ HA was significantly decreased compared with that of control cells $(\mathrm{p}<0.05)$, with cell viability decreased by approximately $60 \%$ with 100 mg/L HA treatment. However, no significant differences in cell viability were observed 
between the cells treated with HA from Indonesia or commercial HA.

\section{Effects of HA on LDH activity}

To confirm the cytotoxicity of HAs, the LDH activity in the medium of cultured cells was measured $48 \mathrm{hr}$ after treatment with $0-100 \mathrm{mg} / \mathrm{L} \mathrm{HA}$ [Fig. 2(b)]. The LDH activity detected in the medium of HUVECs treated with $100 \mathrm{mg} / \mathrm{L} \mathrm{HA}$ from Indonesia or commercial HA increased by $69 \%$ and $54 \%$, respectively, compared with the activity in the medium of control cells. Significant increases in LDH activity were observed when cells were treated with $10-100 \mathrm{mg} / \mathrm{L}$ HA from Indonesia $(\mathrm{p}<0.05)$, and $50-100 \mathrm{mg} / \mathrm{L}$ commercial HA $(p<0.05)$. The time-courses of LDH activity in the medium of cells treated with 50 and $100 \mathrm{mg} / \mathrm{L}$ HA from Indonesia are shown in Figure 2(c). The LDH activity in the medium was found to increase significantly $48 \mathrm{hr}$ after HA treatment. As described above, the chemical characteristics of HA from Indonesia and commercial HA with regard to humification are different, and these differences are thought to be responsible for different levels of cytotoxicity. However, we observed no remarkable differences in the cytotoxicity between the HA samples from either source in this study, as determined by cell viability and LDH activity levels (Fig. 2). The cytotoxicity caused by HAs may, therefore, depend on the binding of heavy metals rather than on the functional groups present in the HAs or their levels of humification.

\section{Effects of HA from Indonesia on caspase expression}

To determine whether HA from Indonesia induces apoptosis, the expression levels of caspases 6, 8, and 9 were investigated by RT-PCR in cells exposed to HA from this source. The levels of caspase mRNA expression in the HA-treated cells are expressed as 
the relative contents when the expression in untreated cells was set to 1.0. As illustrated in Figure 3, significant increases in the expression of caspases 6 and 9 were observed in cells exposed to $50 \mathrm{mg} / \mathrm{L}$ HA from Indonesia, wherein there was an approximately 2fold increase in the expression of these caspases at $24 \mathrm{hr}$ compared with that in control cells. On the other hand, the caspase 8 content decreased by approximately $50 \%$ following HA administration. These results suggest that HA from Indonesia induces apoptosis mediated by the mitochondrial pathway.

\section{Free-SH levels in HUVECs}

Glutathione (GSH), a major cellular thiol component of the cellular antioxidant system, has been shown to play an important role in preserving cells against ROS such as free radicals and peroxides (Alfonso et al., 2003). It is oxidized to GSSG when oxidative stress occurs. To estimate the intracellular oxidation status induced by HA exposure, the levels of free-SH were analyzed in the lysates from HUVECs treated with HA from Indonesia. It was found that the free-SH levels in these cells decreased in a time- and concentration-dependent manner in response to treatment with HA (Fig. 4), whereby treatment with $50 \mathrm{mg} / \mathrm{L}$ reduced the amount of free-SH by $26 \%$ and $63 \%$ at $24 \mathrm{hr}$ and 48 hr after administration, respectively. This suggests that oxidative stress is increased in HUVECs in response to treatment with HA.

\section{Effects of vitamin C on cytotoxicity caused by HA}

To investigate the effects of an antioxidant (vitamin C) on HA-induced cytotoxicity in HUVECs, cells were pre-treated with $10 \mu \mathrm{M}$ vitamin $\mathrm{C}$ for $30 \mathrm{~min}$ before being incubated with 50 or $100 \mathrm{mg} / \mathrm{L}$ HA from Indonesia $(50$ and $100 \mathrm{mg} / \mathrm{L}$ ) for $48 \mathrm{hr}$. Our 
results demonstrated that pre-treatment with vitamin $\mathrm{C}$ significantly decreased LDH activity in the medium of cells exposed to 50 and $100 \mathrm{mg} / \mathrm{L} \mathrm{HA}(\mathrm{p}<0.05)$ [Fig. 5(a)], suggesting that vitamin $\mathrm{C}$ suppressed the cytotoxicity of HA-induced oxidative stress.

\section{Effects of $\mathrm{H}_{2} \mathrm{O}_{2}$ on cytotoxicity caused by $\mathrm{HA}$}

The effects of oxidant $\mathrm{H}_{2} \mathrm{O}_{2}$ on $\mathrm{HA}$-induced $\mathrm{LDH}$ release were also examined in HUVECs treated simultaneously with HA from Indonesia (50 and $100 \mathrm{mg} / \mathrm{L}$ ) and 10 $\mu \mathrm{M} \mathrm{H}_{2} \mathrm{O}_{2}$ for $48 \mathrm{hr}$. LDH activity in the medium of the cells exposed to 50 and 100 mg/L HA from Indonesia was significantly increased by the $\mathrm{H}_{2} \mathrm{O}_{2}$ treatment $(\mathrm{p}<0.05)$ [Fig. 5(b)].

\section{Effects of DFO on cytotoxicity caused by HA}

The effects of an iron chelator, DFO, on the cytotoxicity of HA were also examined in HUVECs simultaneously treated for $48 \mathrm{hr}$ with HA from Indonesia (50 and $100 \mathrm{mg} / \mathrm{L}$ ) and $10 \mu \mathrm{M}$ DFO (Fig. 6). It was found that the presence of DFO significantly inhibited the release of $\mathrm{LDH}$ into the medium of cells exposed to $100 \mathrm{mg} / \mathrm{L}$ HA from Indonesia (p $<0.1)$.

\section{DISCUSSION}

The structure of HA molecules can change according to the environmental background, which may explain the differences observed in the characteristics of the HA obtained from soil and water samples collected from peatland. Based on the results of the elemental analysis carried out in our study, the characteristics of HA obtained from a non-forest (NF) area were similar to those of HA from the Sebangau River (S1) (Table 
II). Therefore, although residents near the Sebangau River are exposed to HA through drinking water, we used HA obtained from a NF area of Indonesia in our studies because of to the difficulty of obtaining large enough amounts of HA from water samples.

It was demonstrated in this study that $50 \mathrm{mg} / \mathrm{L} \mathrm{HA}$ obtained from Indonesia has cytotoxicity in a cell-culture system. This HA concentration is nearly equivalent to that in the drinking water used by some residents of the Sebangau River catchment in Central Kalimantan. It must be emphasized that although HA-related heath disorders have not yet been reported in our study area, an area in Taiwan epidemic for blackfoot disease has been found to contain about 20-200 mg/L HA (Liu et al., 2003; Lu and Liu, 1986). Therefore, the long-term exposure to HA-rich water is a concern as a potential cause of chronic health injury due to the endothelial cell damage elicited by HA.

The HA-induced cytotoxicity observed in this study, as shown in Figure 2, was considered to depend on apoptosis because the expression of caspases 6 and 9 in the cells was increased by treatment with HA (Fig. 3). On the other hand, the expression of caspase 8 was decreased in response to HA administration. As the expression of caspases 8 and 9 are thought to be relevant to death receptor-mediated and mitochondrion-mediated apoptosis, respectively, it is suggested that the apoptosis induced by HA is not related to the death receptor pathway, but rather, the mitochondrial pathway. This explanation corresponds well to the findings of a previous report that showed that the exposure of endothelial cells to HA-induced DNA ladder formation detectable by ligase-mediated PCR (Hseu et al., 2002).

A variety of stimuli can induce apoptotic cell death. For instance, oxidants, including ROS, lipid hydroperoxides, and NO, are believed to be widely involved in oxidative 
stress-induced apoptosis (Higuchi, 2004). The signs and symptoms of blackfoot disease are similar to those of arteriosclerosis and arterial thrombosis (Tseng, 2005), which are known to correlate well with oxidative stress damage to endothelial cells (Laude et al., 2004; Tsai et al., 2011). In addition, previous studies have shown that HA can induce oxidative stress in a variety of cells, including lung epithelial cells and human primary fibroblasts (Cheng et al., 2003; Shufan et al., 2008). This led us to speculate that apoptosis in HUVECs may also be mediated by the effects of HA-induced oxidant generation. While a recent study has indicated that high levels of As and humic substances may play a critical role in causing blackfoot disease in the Chianan plain region of Taiwan (Liao et al., 2011; Selim Reza et al., 2011), the HA examined in this study was found to have very little As content.

We also showed in this study that intracellular free-SH levels in HUVECs are decreased in an HA concentration-dependent and exposure time-dependent manner. We explored the possibility that HA treatment exposed the HUVECs to oxidative stress by examining the effects of vitamin $\mathrm{C}$, an antioxidant, on cell death. As expected, vitamin $\mathrm{C}$ was found to inhibit cell death in response to HA [Fig. 5(a)].

There are many potential sources of ROS generation in cells, including cytosolic xanthine oxidase, membrane NADPH oxidase, and the mitochondrial electron transport system. The photosensitization of $\mathrm{HA}$ also yields active oxygen species such as ${ }^{1} \mathrm{O}_{2}$, $\mathrm{HO} \cdot, \mathrm{HO}_{2} \cdot$, and $\mathrm{O}_{2} \cdot$ (Gau et al., 2001). Such species give rise to the generation of $\mathrm{H}_{2} \mathrm{O}_{2}$ in the environment. In addition, naturally occurring $\mathrm{Fe}(\mathrm{III})$ ions can be photochemically reduced to Fe(II) by HA (Fukushima and Tatsumi, 1999). A combination of $\mathrm{H}_{2} \mathrm{O}_{2}$ generation and $\mathrm{Fe}(\mathrm{III})$ reduction can then leads to a photo-Fenton reaction, in which the forcible oxidant $\mathrm{HO} \cdot$ radical is produced according to the 
following equation (Aguer and Richard, 1996).

$$
\mathrm{Fe}^{2+}+\mathrm{H}_{2} \mathrm{O}_{2} \rightarrow \mathrm{Fe}^{3+}+\mathrm{HO}^{\cdot}+\mathrm{OH}^{\cdot}
$$

The fact that the HA investigated in this study contained several metals, and iron, in particular, suggests that iron ions may have generated the reactive hydroxyl radicals. Indeed, it was shown that LDH release from the cells was increased by the addition of both $\mathrm{H}_{2} \mathrm{O}_{2}$ and $\mathrm{HA}$ to the medium for HUVECs [Fig. 5(b)], while an iron chelator (DFO) decreased the HA-induced lethal cell injury (Fig. 6). Although it was expected that DFO completely decreased the oxygen stress induced by HA, the effects of DFO on cell toxicity were not great. However, it should be noted that HA retained half of its Fe content after DFO treatment (Table III), but that cellular toxicity caused by HA could be prohibited if all Fe could be removed from HA. We, therefore, concluded that HAbound iron may be responsible for mediating oxidative stress induced by HA. In normal tissue, iron rarely exists as a free ion, but rather it is bound to a variety of proteins including hemoglobin, transferrin, or ferritin. It has been suggested that HA could enhance the levels of intracellular chelatable iron in a cell, leading to an increase in ROS generation because of an increase in available iron ions. Although the HA obtained from Indonesia in this study was not found to bind significant amounts of As, oxidative stress was increased in the HUVECs in response to HA treatment. It was postulated that blackfoot disease may be related to the amount of As bound to HA, as it is rare for patients to develop blackfoot disease in Central Kalimantan in Indonesia.

\section{CONCLUSION}

In this study, it was demonstrated that HA obtained in Indonesia had cytotoxicity at concentrations greater than $50 \mathrm{mg} / \mathrm{L}$. This concentration is similar to that found in the 
water used as drinking water in the study area. While the presence of disorders involving HA has not yet been reported in the area of this study, an area of Taiwan that is epidemic for blackfoot disease has been reported to have about $20-200 \mathrm{mg} / \mathrm{L} \mathrm{HA}$. Therefore, the long-term exposure to HA rich water could have the potential to lead to chronic health injury due to the effects of HA on endothelial cells.

Since HA treatment resulted in increase in the expression of caspases 6 and 9, this cytotoxicity was considered dependent upon apoptosis mediated by the mitochondrial pathway (oxidative stress pathway). Supporting this, the cell toxicity caused by HA was increased by $\mathrm{H}_{2} \mathrm{O}_{2}$ treatment, and decreased by vitamin $\mathrm{C}$ treatment. Furthermore, an iron chelator, DFO, inhibited HA-induced lethal cell injury. These results indicate that HA-bound iron could mediate HA-induced oxidative stress, but not its functional groups or humification. To clarify the mechanism of ROS-triggered cell death in response to $\mathrm{HA}$, further investigation will be needed.

\section{DECLARATION OF INTEREST}

The authors declare that they have no competing interests.

\section{ACKNOWLEDGMENTS}

This research was supported by Grants-in-Aid from the Japan Society for the Promotion of Science (No. 20310017 for Kurasaki) and by the JST-JICA Project: Wild Fire and Carbon Management in Peat-Forest in Indonesia. The authors also wish to thank Ms. Miyako Komori, Ms. Yongkun Sun and Mr. Md. Tajuddin Sikder for their technical direction and advice. 


\section{REFERENCES}

Aguer JP, Richard C. 1996. Transformation of fenuron induced by photochemical excitation of humic acids. Pestic Sci 46:151-155.

Alfonso P, Athanase V, Aldo P, Vincenzo DT, Alessandro FC. 2003. The changing faces of glutathione, a cellular protagonist. Biochem Pharmacol 66:1499-1503.

Avena MJ, Wilkinson KJ, 2002. Disaggregation kinetics of a peat humic acid: mechanism and pH effects. Environ Sci Technol 36:5100-5105.

Cavani L, Halladja S, ter Halle A, Guyot G, Corrado G, Ciavatta C, Boulkamh A, Richard C. 2009. Relationship between photosensitizing and emission properties of peat humic acid fractions obtained by tangential ultrafiltration. Environ Sci Technol $43: 4348-4354$.

Cheng ML, Ho HY, Chiu DT, Lu FJ. 1999. Humic acid-mediated oxidative damages to human erythrocytes: a possible mechanism leading to anemia in Blackfoot disease. Free Radic Biol Med 27:470-477.

Cheng ML, Ho HY, Huang YW, Lu FJ. Chiu DT. 2003. Humic acid induces oxidative DNA damage, growth retardation, and apoptosis in human primary fibroblasts. Exp Biol Med 228:413-423.

Fukushima M, Tatsumi K. 1999. Light acceleration of iron(III) reduction by humic acid in the aqueous solution. Colloids Surf A 155:249-258

Gau RJ, Yang H., Suen JL, Lu FJ. 2001. Induction of oxidative stress by humic acid through increasing intracellular iron: a possible mechanism leading to atherothrombotic vascular disorder in blackfoot disease. Biochem Biophys Res Commun 283:743-749.

Higuchi Y. 2004. Glutathione depletion-induced chromosomal DNA fragmentation associated with apoptosis and necrosis. J Cell Mol Med 8:455-464. 
Hseu YC, Huang HW, Wang SY, Chen HY, Lu FJ, Gau RJ, Yang HL. 2002. Humic acid induces apoptosis in human endothelial cells. Toxicol Appl Pharmacol 182:34-43.

Hseu YC, Chen SC, Chen YL, Chen JY, Lee ML, Lu FJ, Wu FY, Lai JS, Yang HL. 2008. Humic acid induced genotoxicity in human peripheral blood lymphocytes using comet and sister chromatid exchange assay. J Hazard Mater 153:784-791.

Huang TS, Lu FJ, Tsai CW. 1995. Tissue distribution of absorbed humic acids, Environ. Geochem Health 17:1-4.

Hur J, Lee BM, Shin HS. 2011. Microbial degradation of dissolved organic matter (DOM) and its influence on phenanthrene-DOM interactions. Chemosphere 85:13601367.

Kalis EJ, Temminghoff EJ, Weng L, van Riemsdijk WH. 2006. Effects of humic acid and competing cations on metal uptake by Lolium perenne. Environ Toxicol Chem 25:702-711.

Laude K, Richard V, Thuillez C. 2004. Coronary endothelial cells: a target of ischemia reperfusion and its treatment? Arch Mal Coeur Vaiss 97:250-254.

Liao VHC, Chu YJ, Su YC, Lin PC, Hwang YH, Liu CW, Liao CM, Chang FJ, Yu CW. 2011. Assessing the mechanisms controlling the mobilization of arsenic in the arsenic contaminated shallow alluvial aquifer in the blackfoot disease endemic area. $\mathbf{J}$ Hazard Mater 197:397-403.

Liu CW, Lin KH, Kuo YM. 2003. Application of factor analysis in the assessment of groundwater quality in a blackfoot disease area in Taiwan. Sci Total Environ 313:7789.

Lu FJ, Liu TM. 1986. Fluorescent compounds in drinking water of blackfoot disease endemic areas, Animal experimental model. J Formosan Med Assoc 85:352-358. 
Lu FJ, Yamamura Y, Yamauchi H. 1988. Studies on fluorescent compounds in water of a well in blackfoot disease endemic areas in Taiwan. J Formosan Med Assoc 87:66-75.

Lu FJ, Huang TS, Lin YS, Pang VF, Lin SU. 1994. Peripheral vasculopathy in rats induced by humic acids. Appl Organomet Chem 8:223-228.

Mills MS, Thurman EM, Ertel J, Thorn KA. 1996. Organic geochemistry and sources of natural aquatic foams. In: Gaffney JS, Marley NA, Clark SB. (Eds.). Humic and Fulvic Acids: Isolation, Structure, and Environmental Role. ACS Publications, New York, pp. 151-192.

Page SE, Wüst RAJ, Weiss D, Rieley JO, Shotyk W, Limin S. 2004. A record of Late Pleistocene and Holocene carbon accumulation and climate change from an equatorial peat bog (Kalimantan, Indonesia): implications for past, present and future carbon dynamics. J Quat Sci 19:625-635.

Radjagukguk B. 1992. Utilisation and management of peatlands in Indonesia for agriculture and forestry. In: Ministry of Agriculture (ed.), Proceedings of the International Symposium on Tropical Peatland. Kuching, Sarawak, May 1991. MARDI, Malaysia, pp. 21-27.

Riggle J, Wandruszka R. 2004. Dynamic conductivity measurements in humic and fulvic acid solutions. Talanta 62:103-108.

Selim Reza AHM, Jean JS, Yang HJ, Lee MK, Hsu HF, Liu CC, Lee YC, Bundschuh J, Lin KH, Lee CY. 2011. A comparative study on arsenic and humic substances in alluvial aquifers of Bengal delta plain (NW Bangladesh), Chianan plain (SW Taiwan) and Lanyang plain (NE Taiwan): implication of arsenic mobilization mechanisms. Environ Geochem Health 33:235-258.

Shufan Q, Gertjan den Hartog JM, Aalt B. 2008. Damage to lung epithelial cells and 
lining fluid antioxidant defense by humic acid. Environ Toxicol Pharmacol 26:96101.

Swift RS. 1996. Organic matter characterization. In: Sparks DL. (ed.). Methods of Soil Analysis, Part 3, Chemical methods. Am Soc Agronomy, Madison, WI, pp. 10181020.

Ting HC, Yen CC, Chen WK, Chang WH, Chou MC, Lu FJ. 2010. Humic acid enhances the cytotoxic effects of arsenic trioxide on human cervical cancer cells. Environ Toxicol Pharmacol 29:117-125.

Tsai KL, Huang YH, Kao CL, Yang DM, Lee HC, Chou HY, Chen YC, Chiou GY, Chen LH, Yang YP, Chiu TH, Tsai CS, Ou HC, Chiou SH. 2012. A novel mechanism of coenzyme Q10 protects against human endothelial cells from oxidative stressinduced injury by modulating NO-related pathways. J Nutr Biochem 23:458-468.

Tseng CH. 2005. Blackfoot disease and arsenic: a never-ending story. J Environ Sci Health C 23:55-74.

Tseng CH, Chong CK, Tseng CP, Centeno JA. 2007. Blackfoot disease in Taiwan: its link with inorganic arsenic exposure from drinking water. Ambio 36:82-84.

Tseng CH. 2008. Cardiovascular disease in arsenic-exposed subjects living in the arseniasis-hyperendemic areas in Taiwan. Atherosclerosis 199:12-18.

Tsutsuki K, Kuwatsuka S. 1978. Chemical studies on soil humic acids, Composition of oxygen containing functional groups of humic acids. Soil Sci Plant Nutr 24:547-560.

Yang HL, Chiu HC, Lu FJ. 1996. Effects of humic acid on the viability and coagulant properties of human umbilical vein endothelial cells. Am J Hematol 51:200-206.

Yang ML, Lee Y, Huang TS, Lu FJ. 2002. Humic acid extracted from Blackfoot diseaseendemic well water induces adipocyte differentiation of C3H10T1/2 ibroblast cells, a 
possible mechanism leading to atherosclerotic-like plaque in Blackfoot disease. Arch Toxicol 76:48-54.

Yonebayashi K, Hattori T. 1988. Chemical and biological studies on environmental humic acids. I. Composition of elemental and functional groups of humic acids. Soil Sci Plant Nurt 34:571-584.

Yu HS, Sheu HM, Ko SS, Chiang LC, Chien CH, Lin SM, Tserng BR, Chen CS. 1984. Studies on blackfoot disease and chronic arsenism in southern Taiwan: With special reference to skin lesions and fluorescent substances. J Dermatol 11:361-370. 


\section{FIGURE CAPTIONS}

Fig. 1. Sampling sites in Central Kalimantan, Indonesia

Fig. 2. Cell viability (a), and LDH activity in the media (b) of HUVECs exposed to HA from Indonesia $(\bigcirc)$ and commercial $(\bigcirc)$ HAs. HUVECs were treated with or without 0-100 mg/L HAs for $72 \mathrm{hr}$. (c) Time-course of LDH activity in the medium of HUVECs exposed to $50 \mathrm{mg} / \mathrm{L}\left(\mathrm{O}_{\text {) and }} 100 \mathrm{mg} / \mathrm{L}(\bigcirc) \mathrm{HA}\right.$ from Indonesia. Values are expressed as the mean \pm S.E.M. of experiments performed in triplicate. $*$ denotes $p<0.05$ compared with the cell viability of untreated cells.

Fig. 3. Effects of HA from Indonesia on the expression of caspases 6, 8, and 9 HUVECs were treated with 0 or $50 \mathrm{mg} / \mathrm{L} \mathrm{HA}$ from Indonesia for $24 \mathrm{hr}$ before the expression of caspases in the cells was assessed, as described in the Material and Methods. Caspase contents are expressed as the relative change in the ratio of caspase expression in treated cells compared to control cells, after caspase levels were calculated as nmol/nmol $\beta$ actin (fold). Values are expressed as the mean \pm S.E.M. of triplicate experiments. ${ }^{*}$ denotes $\mathrm{p}<0.05$ compared to the ratio of caspase expression in untreated cells.

Fig. 4. Concentrations of intracellular free-SH in HUVECs after incubation with or without $0-100 \mathrm{mg} / \mathrm{L}$ HA from Indonesia for $24 \mathrm{hr}(\mathbf{O})$ or $48 \mathrm{hr}(\bigcirc)$. Values are expressed as the mean \pm S.E.M. of triplicate experiments. * denotes $\mathrm{p}<0.05$ compared to the levels of free-SH in untreated cells. 
Fig. 5. Effects of vitamin $\mathrm{C}$ antioxidant (a) and $\mathrm{H}_{2} \mathrm{O}_{2}$ (b) on cytotoxicity induced by treatment with 50 or $100 \mathrm{mg} / \mathrm{L} \mathrm{HA}$ from Indonesia. Vitamin $\mathrm{C}$ was added to the medium 30 min prior to the addition of $\mathrm{HA}$, while $\mathrm{H}_{2} \mathrm{O}_{2}(10 \mu \mathrm{M})$ was added concurrently. LDH activity is expressed as the relative change in the ratio of the control group (fold). Values are expressed as the mean \pm S.E.M. of triplicate experiments. $*$ denotes $\mathrm{p}<0.05$ compared with the LDH activity in cells exposed to HA in the absence of vitamin $\mathrm{C}$ or $\mathrm{H}_{2} \mathrm{O}_{2}$

Fig. 6. Effects of DFO on cytotoxicity induced by treatment with 50 or $100 \mathrm{mg} / \mathrm{L} \mathrm{HA}$ from Indonesia. DFO $(20 \mu \mathrm{M})$ was added to the medium in concurrence with HA. LDH activity is expressed as the relative change in the ratio of the control group (fold). Values are expressed as the mean \pm S.E.M. of triplicate experiments. \# denotes $\mathrm{p}<0.1$ compared with the LDH activity in the cells exposed to HA in the absence of DFO. 